\title{
Optimalisasi Peran Guru Pendidikan Agama Islam dalam Membangun Sikap Keimanan dan Akhlak Mulia pada Peserta Didik
}

\author{
Amrizal \\ Sekolah Tinggi Agama Islam Negeri Bengkalis, Indonesia
}

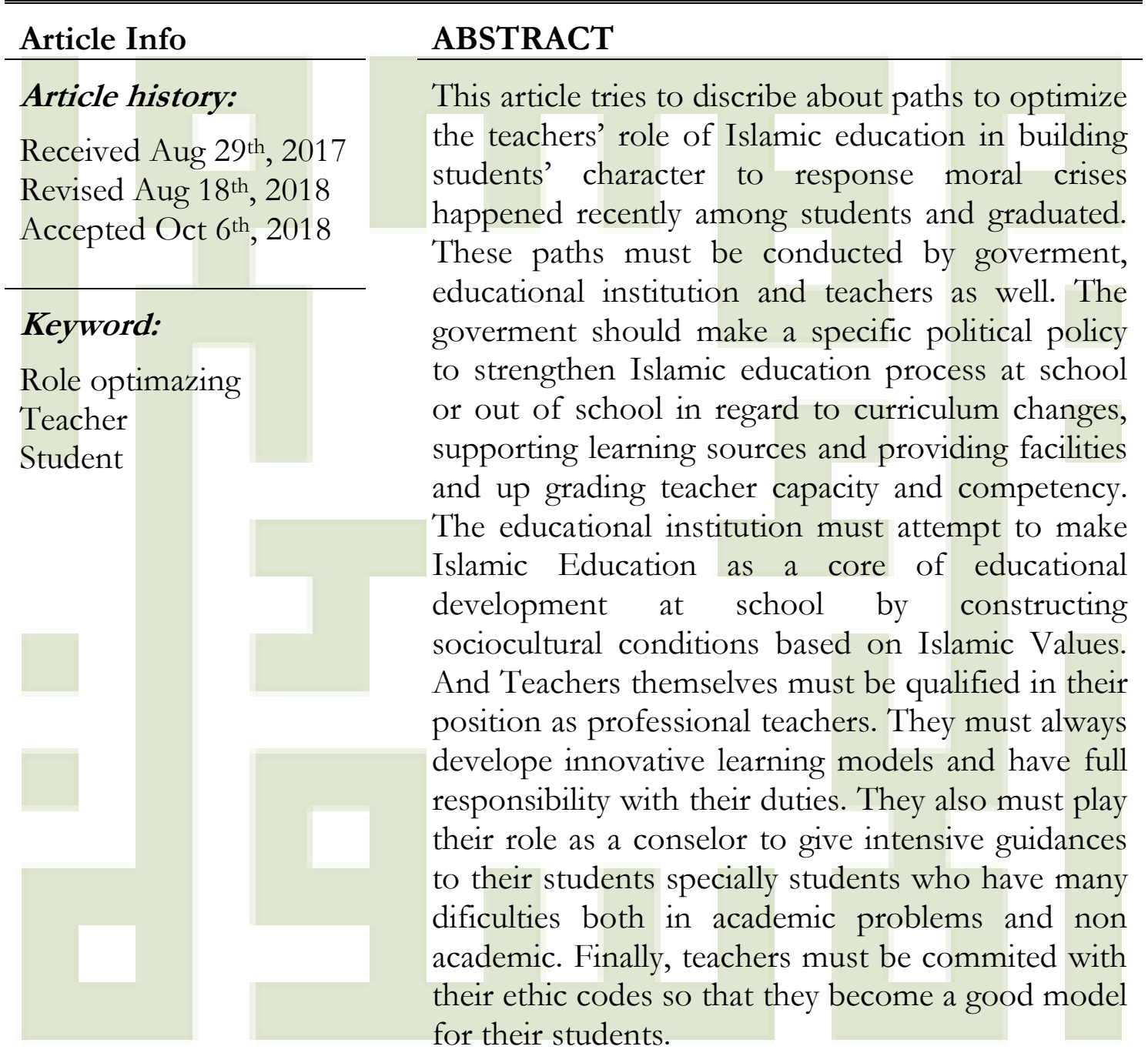

\section{Corresponding Author:}

\section{Amrizal}

Sekolah Tinggi Agama Islam Negeri Bengkalis, Indonesia

Email: amrizalisa@gmail.com 


\section{PENDAHULUAN}

Salah satu tolok ukur keberhasilan proses pendidikan baik di sekolah maupun luar sekolah bisa dilihat dari sejauhmana para lulusannya memiliki karakter dan budi pekerti mulia. Kenapa demikian? karena proses pendidikan tidak hanya memindahkan ilmu pengetahuan dan keterampilan saja kepada peserta didik tapi juga memindahkan nilai-nilai yang dengannya diharapkan terbangun pada diri mereka sikap dan prilaku yang positif. Apabila sebagian besar para lulusan satu lembaga pendidikan mempunyai sikap dan prilaku yang kurang baik, maka tidak berlebihan bila dikatakan bahwa lembaga pendidikan tersebut telah gagal dalam mendidik para peserta didik mereka.

Apa yang dikemukakan sebelumnya secara implisit seiring dengan tujuan Pendidikan Nasional sebagaimana dinyatakan dalam Undang-Undang Sistem Pendidikan Nasional Nomor 2 Tahun 1989 BAB II Pasal 4 yang menyatakan bahwa Pendidikan Nasional bertujuan mencerdaskan kehidupan bangsa dan mengembangkan manusia Indonesia seutuhnya, yaitu manusia yang beriman dan bertaqwa terhadap Tuhan Yang Maha Esa dan berbudi pekerti luhur, memiliki pengetahuan dan keterampilan, kesehatan jasmani dan rohani, kepribadian yang mantap dan mandiri serta rasa tanggung jawab kemasyarakatan dan kebangsaan. ${ }^{1}$ Dalam rumusan tujuan pendidikan nasional ini, persoalan berbudi pekerti luhur mendapatkan penekanan pertama dan utama dalam pencapaian tujuan pendidikan setelah itu baru pengetahuan dan keterampilan dan seterusnya.

Persoalan ini lebih jelas lagi tergambar dalam standar kompetensi lulusan yang ditetapkan pemerintah untuk setiap jenjang pendidikan khususnya untuk dimensi sikap. Untuk lulusan SD/MI/SDLB/Paket A diharapkan Memiliki perilaku yang mencerminkan sikap orang beriman, berakhlak mulia, berilmu, percaya diri, dan bertanggung jawab dalam berinteraksi secara efektif dengan lingkungan sosial dan alam di lingkungan rumah, sekolah, dan tempat bermain. Sedangkan untuk lulusan SMP/MTs/SMPLB/Paket B diharapkan Memiliki perilaku yang mencerminkan sikap orang beriman, berakhlak mulia, berilmu, percaya diri, dan bertanggung jawab dalam berinteraksi secara efektif dengan lingkungan sosial dan alam dalam jangkauan pergaulan dan keberadaannya. Dan Untuk lulusan SMA/ MA/SMK/MAK/SMALB/Paket C Memiliki perilaku yang mencerminkan sikap orang beriman, berakhlak mulia, berilmu, percaya diri, dan bertanggung jawab dalam berinteraksi secara efektif dengan lingkungan sosial dan alam serta dalam menempatkan diri sebagai

${ }^{1}$ Undang-Undang Sistem Pendidikan Nasional Nomor 2 Tabun 1989, (Jakarta: Sinar Grafika, 1999), 4 
cerminan bangsa dalam pergaulan dunia. $^{2}$

Pendidikan Agama, dalam kaitannya dengan persoalan karakter dan budi pekerti mulia, tentu saja lebih memberikan prioritas utama dalam proses penyelenggarannya. Karena ruh dari agama adalah akhlak mulia. Pendidikan Agama dalam hal ini harus berupaya lebih serius dan intensif lagi untuk membangun ruh agama tersebut dalam diri para peserta didik. Menurut UUSPN No 2 tahun 1989, pendidikan agama merupakan usaha untuk memperkuat iman dan ketakwaan terhadap Tuhan Yang Maha Esa sesuai dengan agama yang dianut peserta didik yang bersangkutan dengan memperhatikan tuntutan untuk menghormati agama lain dalam hubungan kerukunan antar umat beragama dalam masyarakat untuk mewujudkan persatuan nasional. Sedangkan dalam Permendiknas no 23 tahun 2006 dirumuskan Standar Kompetensi Kelompok Mata Pelajaran (SK-KMP) Agama dan Akhlak Mulia antara lain: menjalankan ajaran agama yang dianut sesuai dengan tahap perkembangan anak, menunjukkan sikap jujur dan adil, mengenal keberagaman agama, budaya, suku, ras, dan golongan sosial ekonomi di lingkungan sekitarnya, menunjukkan kecintaan dan kepedulian terhadap sesama manusia dan lingkungan sebagai makhluk ciptaan Tuhan, menghargai

2Permendikbud Nomor 54 Tabun 2013 tentang Standar Kompetensi Lulusan perbedaan pendapat dalam menjalankan ajaran agama.

Pendidikan Agama Islam sebagai bagian dari pendidikan agama yang secara spesifik dikontruksi berdasarkan persfektif Islam tentu juga harus memainkan peran yang sama. Pendidikan Agama Islam (PAI) dapat dilihat dari dua sudut pandang. Yaitu PAI sebagai aktivitas dan PAI sebagai fenomena. PAI sebagai aktivitas berarti upaya yang secara sadar dirancang untuk membantu seseorang atau sekelompok orang dalam mengembangkan pandangan hidup (bagaimana orang akan menjalani dan memanfaatkan hidup dan kehidupannya), sikap hidup dan keterampilan hidup-baik bersifat manual (petunjuk praktis) maupun mental- dan sikap sosial yang bernapaskan atau dijiwai oleh ajaran serta nilai-nilai Islam. Sedangkan PAI sebagai fenomena adalah peristiwa perjumpaan antara dua orang atau lebih dan/atau penciptaan suasana yang dampaknya ialah berkembangnya suatu pandangan hidup yang bernapaskan atau dijiwai oleh ajaran dan nilai-nilai Islam, yang diwujudkan dalam sikap hidup serta keterampilan hidup pada salah satu atau beberapa pihak. ${ }^{3}$

Sejauhmana lulusan lembaga pendidikan yang mendapatkan proses pendidikan agama Islam sebelumnya telah memiliki perilaku yang mencerminkan sikap orang beriman dan berakhlak mulia?. Inilah

${ }^{3}$ Muhaimin, Rekonstruksi Pendidikan Islam, (Jakarta: RajaGrafindo Persada, 2009), 51 
yang menjadi pertanyaan kunci yang mendasari tulisan ini. Tanpa bermaksud menafikan keberhasilan proses pendidikan agama Islam, ada sejumlah data yang menunjukkan sepertinya penyelengaraan pendidikan agama Islam di sekolah-sekolah perlu dilakukan evaluasi secara komprehensif.

Dalam kaitannya dengan kemampuan membaca al-quran, data Badan Pusat Statistik (BPS) tahun 2013 menyebutkan ada sekitar 54 persen dari total populasi umat Islam di Indonesia yang tidak bisa membaca Alquran. ${ }^{4}$ Angka ini tidak jauh berbeda dengan hasil survei Institut Ilmu Al-Qur'an (IIQ) Jakarta tahun 2005 yang menyebutkan bahwa 65 persen umat Islam di Indonesia ternyata masih buta aksara Al-Qur'an. 35 persennya hanya bisa membaca Alquran saja. Sedangkan yang membaca dengan benar hanya 20 persen.

Selanjutnya tentang pergaulan bebas di kalangan pelajar, hasil survey Dinas Kesehatan Aceh menemukan maraknya kasus seks bebas bagi kalangan pelajar di daerah Lhokseumawe dan Banda Aceh. Berdasarkan data yang diperoleh, Lhokseumawe menduduki peringkat pertama terbanyak pelaku seks pranikah di kalangan pelajar, yaitu 70 persen, menyusul Banda Aceh sebanyak 50 persen. ${ }^{5}$ Data ini sangat mengejutkan berbagai pihak sekaligus memalukan sekali apalagi

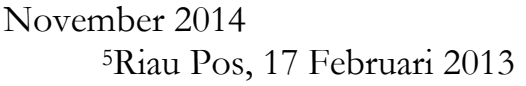

ditengah upaya penerapan syariat Islam di Nangroe Aceh Darussalam ternyata angka praktek perzinaan di kalangan pelajar cukup tinggi dan sangat mengkhawatirkan. Bagaimana dengan daerah lain di Indonesia? menurut hasil survey yang pernah dirilis oleh LSCK PUSBIH (Lembaga Studi Cinta dan Kemanusiaan serta Pusat Pelatihan Bisnis dan Humaniora) pada tahun 2002 dari 1600 responden menemukan $97,05 \%$ para mahasiswi di 16 perguruan tinggi di kota Yogyakarta mengaku pernah melakukan seks pra nikah. Kemudian tahun 2007 Komisi Nasional Perlindungan Anak juga pernah merilis data hasil survei di 12 kota besar di Indonesia, dimana 62,7\% remaja yang duduk di bangku SMP (Sekolah Menengah Pertama) pernah berhubungan intim dan $21,2 \%$ siswi SMA (Sekolah Menengah Atas) pernah menggugurkan kandungannya. Selanjutnya tahun 2010 BKKBN (Badan Kependudukan dan Keluarga Bencana Nasional) juga pernah merilis sekitar $51 \%$ para remaja seJabodetabek juga melakukan hal yang serupa. ${ }^{6}$

Kemudian tentang penyalahgunaan Narkoba di kalangan pelajar, Badan Narkotika Nasional (BNN) merelease data terkait pengguna narkotika dan obat-obatan terlarang (narkoba) di 2014 menyebutkan, 22 persen pengguna narkoba di Indonesia merupakan pelajar dan mahasiswa. Sementara, jumlah

${ }^{6}$ www.kompasiana.com. 
penyalahgunaan narkotika pada anak yang mendapatkan layanan rehabilitasi pada 2015, tercatat anak usia di bawah 19 tahun berjumlah 348 orang dari total 5.127 orang yang direhabilitasi di tahun itu. Sedangkan jumlah tersangka kasus narkotika berdasarkan kelompok umur pada 2015 yakni anak usia sekolah dan remaja di bawah 19 tahun berjumlah 2.186 atau 4,4 persen dari total tersangka. ${ }^{7}$

Data-data ini menggambarkan sepertinya ada persoalan serius dalam kaitannya dengan sikap dan prilaku para lulusan lembaga pendidikan kita yang notabene mereka tentunya sudah diberikan pendidikan agama, kalau mereka muslim tentu pendidikan agama Islam. Dimana letak salahnya sebenarnya? tentu penyebabnya sangat beragam dan kompleks. Akan tetapi sedikit banyak sumber masalahnya ada pada para pendidik kita. Karena walau bagaimanapun, guru dalam hal ini adalah ujung tombak keberhasilan proses pendidikan agama. Guru sesuai dengan tugas pokok dan fungsinya menjalankan peran untuk mendidik, mengajar, membimbing, membina, memberikan contoh tauladan, mengawasi, dan mengevaluasi para peserta didik mereka. Seberapa besar peran yang dimainkan Guru PAI dalam menjalankan tupoksinya akan berkorelasi sangat siqnifikan dengan perubahan prilaku pada peserta didik mereka.

\footnotetext{
${ }^{7}$ www.netralnews.com, $\quad$ Rabu, 28 September 2016
}

Disinilah letak pentingnya para guru Pendidikan Agama Islam untuk mengoptimalkan peran mereka dalam mendidik para peserta didik mereka. Para guru PAI harus senantiasa berupaya meningkatkan kapasitas pribadi dan kompetensi mereka agar proses pendidikan agama Islam bisa membuahkan hasil yang maksimal khususnya dalam membangun karakter Islami pada diri peserta didik mereka yang diharapkan bersifat permanen sehingga tingkat penyimpangan prilaku di kalangan pelajar dan lulusan bisa diminimalisir.

\section{PERAN GURU PENDIDIKAN AGAMA ISLAM}

Peran guru pendidikan agama Islam secara garis besar tidak jauh berbeda dengan peran guru pada umumnya. Peran tersebut berhubungan dengan tugas dan fungsi mereka, yaitu mengajar (transfer of knowledge) kepada orang lain, pengelola pembelajaran (manager of learning), pengarah pembelajaran (director of learning), fasilitator dan perencana (planner of future society). ${ }^{8}$ Letak perbedaannya dengan pendidikan pada umumnya, pendidikan Islam dikonstruksi berdasarkan persfektif Islam. Hal ini sebagaimana ditulis Ahmad Tafsir dalam bukunya Filsafat Pendidikan Islam bahwa kata "Islam" yang dilekatkan pada kata Pendidikan

${ }^{8}$ Hamzah B. Uno, Model Pembelajaran, Menciptakan Proses Belajar Mengajar yang Kreatif dan Efektif, (Jakarta: Bumi Aksara, 2008), 154 
menggambarkan ciri pendidikan tersebut yang berdasarkan Islam dalam hal ini bersumberkan dari AlQuran dan Hadits serta ilmu-ilmu Keislaman yang tersajikan dalam kitab-kitab turats yang ditulis para ulama terdahulu. ${ }^{9}$

Menurut Undang-Undang Republik Indonesia Nomor 14 Tahun 2005 tentang Guru dan Dosen menyatakan bahwa "Guru adalah pendidik profesional dengan tugas utama mendidik, mengajar, membimbing, mengarahkan, melatih, menilai, dan mengevaluasi peserta didik pada pendidikan anak usia dini jalur pendidikan formal, pendidikan dasar dan pendidikan menengah." ${ }^{10}$

Ramayulis menyatakan ada tiga tugas secara khusus guru di dalam Islam, yaitu:

a. Sebagai pengajar (instruksional) yang bertugas merencanakan program pengajaran dan melaksanakan program yang telah disusun, dan memberikan penilaian setelah program itu dilaksanakan.

b. Sebagai pendidik (edukator) yang mengarahkan peserta didik pada tingkat kedewasaan yang berkepribadian Islam, seiring dengan tujuan Allah menciptakan manusia.

c. Sebagai pemimpin (managerial) yang memimpin dan mengendalikan diri sendiri, peserta didik dan masyarakat

${ }^{9}$ Ahmad Tafsir, Filsafat Pendidikan Islam, (Jakarta: Remaja Rosdakarya, Jakarta, 2006), 23 ${ }^{10}$ Undang-undang Nomor 14 Tabun 2005 tentang Guru dan Dosen, Jakarta: Visimedia, 2008), h. 35 yang terkait. Menyangkut upaya pengarahan, pengawasan, pengorganisasian, pengontrolan, partisipasi atas program yang dilakukan itu. ${ }^{11}$

Adapun tugas guru Pendidikan Agama Islam menurut Zakiah Darajat dkk, adalah sebagai berikut:

a. Tugas pengajaran atau guru sebagai pengajar.

Sebagai seorang pengajar, guru bertugas membina perkembangan pengetahuan, sikap dan keterampilan. Guru mengetahui bahwa pada akhir setiap satuan pelajaran kadangkadang hanya terhjadi perubahan dan perkembangan pengetahuan saja.

Dengan kata lain, bahwa kemungkinan besar selama proses belajar-mengajar hanya tercapai perkembangan di bagian minat. Sedang efek dan transfernya kepada keseluruhan perkembangan sikap dan kepribadian berlangsung di luar situasi belajar-mengajar itu sendiri.

Hal demikian itu tampaknya bersifat umum, walaupun sesungguhnya kurang memenuhi harapan dari pengajaran agama. Dari kenyataan itu pulalah terbukti bahwa peranan guru sebagai pendidik dan pembimbing masih berlangsung terus

${ }^{11}$ Ramayulis, Ilmu Pendidikan Islam, (Jakarta: Kalam Mulia, 2013), Cet. ke-10, 110111 
walaupun tugasnya sebagai pengajar telah selesai.

b. Tugas bimbingan atau guru sebagai pembimbing dan pemberi bimbingan.

Guru sebagai pembimbing dan pemberi bimbingan adalah dua macam peranan yang mengandung banyak perbedaan dan persamaannya. Keduanya sering dilakukan oleh guru yang ingin mendidik dan yang bersikap mengasihi dan mencintai murid.

Sifat khas anak seperti ketidaktahuan (kebodohan), kedangkalan dan kurang pengalaman, telah mengundang guru untuk mendidik dan membimbing mereka, sesungguhnya anak itu sendiri mempunyai "dorongan" untuk menghilangkan sifat-sifat demikian dengan tenaganya sendiri atau menurut kuasanya, disamping bantuan yang diperolehnya dari orang dewasa (guru) melalui pendidikan.

c. Tugas administrasi

Guru bertugas pula sebagai tenaga administrasi, bukan berarti sebagai pengawai kantor, melainkan sebagai pengelola kelas atau pengelola (manajer) interaksi belajarmengajar. Meskipun masalah pengelolaan ini dapat dipisahkan dari masalah mengajar dan bimbingan, tetapi tidak seluruhnya dapat dengan mudah diidentifikasi. Sesungguhnya ketiga hal itu saling berhubungan dan tidak terpisahkan dari mengajar itu sendiri. ${ }^{2}$ Baik Ramayulis maupun Zakiah Darajat sepertinya memliki sudut pandang yang tidak jauh berbeda dalam menguraikan peran guru pendidikan Agama Islam hanya saja ungkapan yang digunakan berbeda. Keduanya menekankan peran guru kepada tiga hal pokok; sebagai pengajar, pendidik dan pengatur.

Guru Pendidikan Agama Islam diposisikan untuk menjadikan siswa memiliki kecerdasan spiritual, yang dapat membawa keberhasilan dalam mendidik sehingga tercapailah visi pendidikan agama, yaitu terbentuknya peserta didik yang memiliki kepribadian yang dilandasi keimanan dan ketaqwaan terhadap Allah SWT dan tercapainya pula misinya yaitu tertanamnya nilai-nilai akhlak yang mulia dan budi pekerti yang kokoh yang tercermin dalam keseluruhan sikap dan perilaku sehari-hari. Hal ini sejalan dengan apa yang dikemukakan Mohd. Atiyah al-Abrasyi dalam kitabnya al-Tarbiyah $f i$ al-Islam bahwa pendidikan akhlak adalah pusat yang di sekelilingnya berputar program dan kurikulum pendidikan Islam. pendidikan akhlak adalah jiwa pendidikan Islam. sebab tujuan pertama dan termulia pendidikan Islam adalah menghaluskan akhlak dan mendidik jiwa. ${ }^{13}$

12Zakiah Daradjat, Metodik Kbusus Pengajaran Agama Islam, (Jakarta: Bumi Aksara, 2011), Cet. ke-5, 265-267

${ }^{13}$ Mohd. Atiyah al-Abrasyi, sebagaimana dikutip Hasan Langgulung, Asas-Asas Pendidikan Islam, (Jakarta: Pustaka Al-Husna Baru, 2003), 113 
Peran guru yang diungkapkan dalam redaksi bahasa kontemporer diantaranya seperti diungkap Watten B. sebagaimana dikutip oleh Piet A. Sahertian, peran guru adalah sebagai tokoh terhormat dalam masyarakat sebab ia nampak sebagai orang yang berwibawa, sebagai penilai, sebagai seorang sumber karena ia memberi ilmu pengetahuan, sebagai pembantu, sebagai wasit, sebagai detektif, sebagai obyek identifikasi, sebagai penyangga rasa takut, sebagai orang yang menolong memahami diri, sebagai pemimpin kelompok, sebagai orang tua/wali, sebagai orang yang membina dan memberi layanan, sebagai kawan sekerja dan sebagai pembawa rasa kasih sayang. ${ }^{14}$ Sedang menurut Oliva, peran guru adalah sebagai penceramah, nara sumber, fasilitator, konselor, pemimpin kelompok, tutor, manajer, kepala laboratorium, perancang program dan manipulator yang dapat mengubah situasi belajar. ${ }^{15}$

Sejalan dengan penadapat Oliva, Sardiman AM, menyatakan bahwa peran guru adalah sebagai informator, organisator, motivator, direktor, inisiator, transmitter, fasilitator, mediator dan evaluator. ${ }^{16}$ Lebih lanjut Sardiman menerangkan bahwa:

a. Informator berarti guru harus melaksanakan cara-cara mengajar informatif,

14Piet Suhertian, Profil Pendidik Profesional, (Yogyakarta: Andi Offset, 1994), 14

15Ibid., 16

${ }^{16}$ Sardiman AM, Interaksi dan Motivasi Belajar Mengajar, (Jakarta: RajaGrafindo Persada, 2000), 142-144 laboratorium, studi lapangan dan sumber informasi kegiatan akademik maupun umum.

b. Organisator berarti guru diharapkan mampu mengorganisasikan sedemikian rupa komponen-komponen yang berkaitan dengan kegiatan belajar mengajar sehingga dapat dicapai efektifitas dan efisiensi belajar pada diri siswa.

c. Motivator berarti guru dituntut mampu merangsang dan memberikan dorongan serta reinforcement untuk mengkomunikasikan potensi siswa, menumbuhkan aktivitas dan daya cipta (kreatif) sehingga akan terjadi dinamika di dalam proses pembelajaran sebagai usaha untuk meningkatkan kegairahan dan pengembangan kegiatan belajar siswa.

d. Direktur berarti guru harus memberikan bimbingan dan pengarahan tentang kegiatan belajar siswa sesuai dengan tujuan yang akan dicapai peranan ini akan menonjolkan jiwa kepemimpinan guru dalam menjalankan pekerjaan profesional.

e. Inisiator berarti guru dipandang sebagai pencetus ide-ide kreatif dalam proses belajar yang dapat dicontoh oleh siswanya.

f. Transmitter berarti guru bertindak sebagai penyebar kebijakan pendidikan dan pengetahuan dalam kegiatan belajar mengajar. 
g. Fasilitator berarti guru hendaknya memberikan fasilitas atau kemudahan dalam proses belajar mengajar, misalnya dengan menciptakan suasana kegiatan belajar yang sedemikian rupa, serasi dengan perkembangan siswa sehingga interaksi belajar mengajar dapat berlangsung efektif.

h. Mediator berarti guru diartikan sebagai penengah atau pemberi jalan untuk mengatasi kemacetan dalam kegiatan belajar mengajar siswa di samping penyedia media sekaligus mengorganisasikan penggunaan media.

i. Evaluator berarti guru berhak menilai prestasi akademik dan prilaku sosial sebagai penentu berhasil atau tidaknya siswa dalam belajar. Evaluasi tidak hanya sebatas ekstrinsik saja, tetapi juga menyentuh aspek intrinsik yang diwujudkan dalam prilaku sehingga guru dalam menjatuhkan nilai akan lebih berhati-hati.

Sedangkan Syaiful Bahri Djamarah melengkapi beberapa pendapat di atas dengan menyatakan bahwa peran guru adalah sebagai korektor, inspirator, informator, organisator motivator, inisiator, fasilitator, pembimbing, demonstrator, pengelola kelas, mediator, supervisor dan evaluator. ${ }^{17}$ Lebih lanjut Djamarah memperjelas

${ }^{17}$ Syaiful Bahri Djamarah, Guru dan Anak Didik dalam Interaksi Edukatif, (Jakarta: Reneka Cipta, Jakarta), 43-48 keterangan dengan memberikan penjelasan pada masing-masing peran tersebut yaitu :

a. Korektor berarti guru berhak menilai dan mengoreksi sikap, tingkah laku dan perbuatan siswa, sikap prilaku dan perbuatan ini dipengaruhi oleh nilai-nilai yang melekat pada diri siswa. Oleh karena itu guru harus dapat membedakan antara nilai yang baik dan nilai yang buruk, nilai yang baik guru harus mempertahankan dan nilai yang buruk harus direduksi dari jiwa dan watak siswa.

b. Inspirator, berarti guru dituntut untuk memberikan petunjuk tentang bagaimana cara belajar yang baik, petunjuk tersebut dapat bertolak dari pengalaman atau pengetahuan yang telah didapat oleh guru sehingga mampu untuk memecahkan problematika yang dihadapi siswa.

c. Informator, berarti guru harus memberikan informasi tentang perkembangan sains dan teknologi, selain sejumlah bahan pelajaran untuk setiap mata pelajaran yang telah diprogramkan oleh guru. Informasi ini harus baik sehingga sesuai dengan kebutuhan dan perkembangan siswa.

d. Organisator berarti guru memiliki kegiatan pengelolaan aktivitas akademik, menyusun tata tertib kelas, menyusun kalender akademik dan 
sebagainya.

Semua

diorganisasikan sehingga dapat mencapai efektivitas dan efisiensi dalam belajar pada diri siswa.

e. Motivator berarti guru harus memotivasi siswa agar bergairah dan aktif dalam belajar. Untuk itu motif-motif yang melatar belakangi siswa dalam belajar harus dipacu sedemikian rupa sehingga mereka mampu belajar secara mandiri sesuai dengan kebutuhannya.

f. Inisiator berarti guru menjadi pencetus ide-ide progresif dalam pendidikan sehingga prosesnya tidak ketinggalan zaman dan mengalami perkembangan yang lebih baik dari keadaan sebelumnya.

g. Fasilitator, berarti guru menyediakan fasilitas belajar sehingga dapat tercipta lingkungan belajar yang menyenangkan siswa dan memudahkan aktivitas belajar mereka.

h. Pembimbing, berarti kehadiran guru di sekolah adalah untuk membimbing siswa menjadi manusia dewasa yang berprilaku secara mandiri, awalnya siswa tergantung pada bantuan guru karena kekurangmampuannya. Namun dengan bimbingan guru, rasa ketergantungan tersebut semakin berkurang dikarenakan tingkat kedewasaan telah berkembang sehingga nantinya mampu berdiri sendiri (mandiri) dalam belajar. i. Demonstrator berarti guru harus memperjelas penjelasannya melelui peragaan alat dan gerak-gerak ritme tubuh sehingga memudahkan pemahaman siswa, dengan demikian guru dapat membantu memperjelas pemahaman siswa sehingga diharapkan adanya kesejalanan antara keinginan guru dan pemahaman siswa dan diantara mereka tidak terjadi salah pengertian.

j. Pengelolaan kelas, berarti guru berperan dalam mengelola proses pembelajaran. Ia hendaknya mengatur penempatan masing-masing siswa sesuai dengan proporsinya, menjadi dari kegaduhan dan membuat suasana kelas semakin menyenangkan sehingga aktivitas mengajar semakin optimal.

k. Mediator, berarti guru harus memiliki pengetahuan dan pemahaman yang cukup terhadap penggunaan berbagai jenis media pendidikan sebagai alat komunikasi yang efektif dalam proses pembelajaran sehingga dapat membantu memperjelas eksplanasi dan sebagai jalan pemecahan masalah.

1. Supervisor, berarti guru harus membantu memperbaiki dan menilai secara kritis terhadap proses pembelajaran. Untuk itu teknik-teknik supervisi harus dikuasai oleh guru sehingga akan membantu memperbaiki 
situasi dan kondisi belajar mengajar. Teknik-teknik tersebut dapat diperoleh melalui jabatan, pengalaman, pendidikan, kecakapan dan ketrampilan-ketrampilan yang dimilikinya serta sifat-sifat kepribadian yang menonjol.

m.Evaluator, berarti guru bertugas menilai aspek-aspek instrinsik (kepribadian) dan ekstrinsik yang mengarah kepada pencapaian prestasi verbal siswa. Keduanya bermanfaat bagi perkembangan jiwa dan prilaku mereka dalam pencapaian prestasi yang optimal.

Dari beberapa pendapat tentang peran guru di atas, bisa dipahami bahwa peran guru tidak hanya bertindak sebagai pengajar saja, tetapi haruslah sanggup bertindak sebagai korektor, inspirator, informator, motivator, fasilitator, pembimbing, demonstrator, pengelola kelas, mediator, supervisor, organisator, direktor, transmitter, dan evaluator. Hal ini diperlukan sebagai bekal untuk pengabdian dirinya dalam meraih cita-cita mulia yaitu mencapai tujuan pendidikan universal.

Guru pendidikan agama Islam dalam hal ini tentu lebih banyak menekankan peran sebagai Inspirator, motivator, pembimbing dan supervisor dan evaluator dengan sasaran utama bagaimana terbangunnya sikap keimanan dan akhlak mulia pada peserta didik mereka.

\section{OPTIMALISASI PERAN GURU PENDIDIKAN AGAMA ISLAM}

Setuju atau tidak setuju, peran guru PAI sebagai pendidik masih belum optimal. Dalam redaksi Abuddin Nata profesionalisme guru mulai dipertanyakan eksistensinya secara fungsional. Hal ini antara lain disebabkan oleh munculnya serangkaian fenomena para lulusan pendidikan yang secara moral cenderung merosot dan secara intelektual akademis juga kurang siap untuk memasuki lapangan kerja. ${ }^{18}$

Lebih lanjut Abuddin Nata menyorot akar permasalahannya bermula dari persoalan profesionalisme guru dalam menjalankan tugas mereka dan sejauhmana kedisiplinan mereka dalam memematuhi kode etik. Baik menyangkut penguasaan mereka terhadap bidang yang diajarkannya, kemampuan mereka menyampaikan atau mengajarkan ilmu yang dimilikinya, atau kepatuhan mereka terhadap kode etik yang lebih dikhususkan penekanannya pada perlunya memiliki akhlak yang mulia. ${ }^{19}$

Ahmad Tafsir dalam redaksi yang sedikit pedas menyorot eksistensi guru sebagai respon terhadap merosotnya akhlak para peserta didik dan lulusan pendidikan akhir-akhir ini menyatakan bahwa sebagian guru dalam menjalankan tugasnya memiliki kecenderungan

${ }^{18}$ Abuddin Nata, Manajemen Pendidikan, Mengatasi Kelemahan Pendidikan Islam di Indonesia, (Jakarta: Kencana, 2010), 151

19Ibid., 156 
profit oriented, yaitu mengedepatkan aspek material yang bersifat untung rugi (ekonomis). ${ }^{20}$ Perubahan paradigma guru dalam menjalankan tugas profesional ini mengecilkan peran dan tanggung jawab mereka dalam mendidik para peserta didik mereka.

Terlepas apapun penyebab kemerosotan moral yang terjadi di kalangan peserta didik dan lulusan pendidikan, upaya untuk meminimalisirnya harus dilakukan semampu mungkin agar derajatnya tidak semangkin meningkat semampu mungkin. Para guru PAI memiliki tanggung jawab moral memperbaiki sikap dan prilaku para peserta didik mereka. Dalam kaitannya dengan ini, optimalisasi peran guru PAI harus dilakukan. Optimalisasi peran guru PAI tersebut harus melibatkan berbagai unsur, yaitu pemerintah, lembaga pendidikan dan guru PAI itu sendiri.

Pemerintah dalam kaitannya dengan hal ini harus merumuskan dan menetapkan kebijakan khusus yang memberikan penguatan pembelajaran PAI di sekolah maupun di luar sekolah baik menyangkut perubahan kurikulum, fasilitas dan sumber belajar serta peningkatan kapasitas dan profesionalitas guru PAI. Persoalan sedikitnya jumlah jam pelajaran PAI di sekolah-sekolah menjadi persoalan klasik yang sepertinya belum ada jalan keluarnya. Selain itu tidak

${ }^{20}$ Ahmad Tafsir, Ilmu Pendidikan dalam Persfektif Islam, (Bandung: Remaja Rosdakarya: 1994), 77 terintegrasi sistem pembelajaran PAI baik di sekolah maupun luar sekolah (madrasah) ikut memberikan kontribusi ketidakefektifitas pembelajaran PAI. Belum lagi keterbatasan fasilitas pembelajaran PAI baik teoretis maupun praktis di sekolah-sekolah. Satu hal yang menjadi masalah selama ini tidak adanya sinergisitas antara guru PAI dan orang tua peserta didik dalam pencapaian tujuan pembelajaran PAI. Masing-masing pihak sepertinya jalan-jalan masing, tidak ada komunikasi dan kerjasama sehingga mekanisme kontrol tidak terbangun. Sebagian besar orang tua peserta didik menyerahkan sepenuhnya tanggung jawab untuk mengajar dan mendidik anak-anak mereka. sementara guru memiliki keterbatasan waktu dan tenaga dalam menjalankan tugas mereka. Intervensi pemerintah melalui kebijakan diyakini bisa memaksimalkan lagi peran guru PAI dan memberikan keleluasaan kepada mereka dalam menjalankan tupoksi mereka.

$\begin{array}{llr}\text { Pemerintah } & \text { jangan lagi } \\ \text { memandang } & \text { sebelah } & \text { mata }\end{array}$ pendidikan agama Islam khususnya di sekolah-sekolah umum karena jika dilihat perbandingan sekolah umum dan sekolah agama (madrasah); jauh lebih banyak sekolah umum daripada sekolah agama (madrasah). Pendidikan agama Islam diyakini bisa membentengi peserta didik dari prilaku-prilaku menyimpang. Apalagi saat ini tidak sedikit pelaku tindak kejahatan dan asusila dilakoni 
generasi muda yang notabene berasal dari kalangan pelajar dan mahasiswa.

Selain pemerintah, lembaga pendidikan sangat dituntut perannya dalam penguatan pembelajaran PAI di lingkungannya masing-masing. Pendidikan agama yang berorientasi pada peningkatan kualitas keimanan dan ketakwaan terhadap Tuhan YME perlu dijadikan core pengembangan pendidikan di sekolah, terutama dalam mengantisipasi krisis moral atau akhlak. $^{21}$

Gagasan ini menjadi penting karena proses internalisasi karakter peserta didik berlangsung melalui proses interaksi dan komunikasi mereka dengan lingkungan dimana mereka berada. menurut teori sosiologis, sekolah merupakan miniatur masyarakat yang di dalamnya tercipta interaksi antara satu pihak dengan pihak lainnya dengan membawa simbol-simbol atau memperkenalkan latar belakang sosial, budaya, agama dan tradisi masing-masing. Meskipun demikian, mereka diatur dan terikat oleh peraturan atau tata tertib sekolah dan kode etik yang disepakati menjadi produk bersama. Karena pendidikan agama merupakan core pengembangan pendidikan, maka aturan atau kode etik tersebut harus diwarnai nilai-nilai agama.

Lembaga pendidikan sesuai dengan kewenangan yang dimilikinya harus membangun kondisi

${ }^{21}$ Muhaimin, Nuansa Baru Pendidikan Islam, Mengurai Benang Kusut Dunia Pendidikan, (Jakarta: RajaGrafindo Persada, 2006), 102 sosiokultural di sekolahnya berdasarkan nilai-nilai agama sehingga tercipta suasana dan iklim relijius di dalamnya. Setiap warga sekolah harus menyesuaikan diri dengan dunia sosiokultural di sekolah tersebut. interaksi antarpeserta didi itu sendiri (laki-laki dan perempuan), interaksi antara peserta didik dengan guru dan pimpinan sekolah serta tenaga kependidikan lainnya, guru dengan sesama guru, guru dengan kepala sekolah dan wakil kepala sekolah serta tenaga kependidikan lainnya dan seterusnya, yang terikat oleh kode etik tersebut akan mengalami proses institusionalisasi (objektivasi). Masing-masing individu warga sekolah akan mengidentifikasikan diri dengan kode etik atau aturan dan norma yang berlaku di sekolah tempat individu menjadi anggotanya. $^{22}$

Guru PAI dalam hal ini tentu saja diharapkan kontribusinya dalam merumuskan dan mengkonstruksi seperti apa kondisi sosiokultural yang ingin diciptakan di sekolahnya. Paling tidak kondisi tersebut mengacu pada penanaman sikap keimanan dan akhlak mulia.

Ujung tombak optimalisasi peran guru PAI tentu saja berada di tangan guru PAI itu sendiri. Karena di tangan merekalah keberhasilan proses pendidikan Agama Islam itu diletakkan. Sejauhmana sikap dan prilaku positif terbangun pada peserta didik sangat ditentukan oleh seberapa besar peran guru PAI yang sudah dijalankan semaksimal

22Ibid., 103 
mungkin. Ada persepsi di masyarakat, meskipun tidak sepenuhnya tepat, ketika para peserta didik menyimpang prilakunya, orang pertama yang dipersoalkan perannya adalah guru PAI. Karena guru PAI dianggap orang yang paling bertanggung jawab dalam pembentukan moral peserta didik.

Langkah pertama guru PAI harus meng-up grade penguasaannya terhadap ilmu pengetahuan yang akan diajarakan kepada peserta didik. Mereka harus benar-benar menjadi guru yang ahli di bidangnya. Selanjutnya karena bidang pengetahuan apa pun selalu mengalami perkembangan, maka seorang guru juga harus terusmenerus meningkatkan dan mengembangkan ilmu yang diajarkannya sehingga tidak ketinggalan zaman. Untuk dapat melakukan peningkatan dan pengembangan ilmu yang diajarkanya itu, seorang guru harus secara terusmenerus melakukan penelitian dengan menggunakan berbagai macam metode.

Selanjutnya guru PAI harus memiliki kemampuan menyampaikan atau mengajarkan ilmu yang dimilikinya kepada para peserta didiknya secara efektif dan efisisien. Aspek inilah yang menentukan sejauhmana internaliasi karakter akan terbangun pada diri peserta didik. Inovasi-inovasi dalam pembelajaran PAI harus dikembangkan oleh setiap guru agar kegiatan pembelajaran tidak terkesan monoton dan konvensional. Pembelajaran PAI sedapat mungkin tidak hanya berupa indoor activities (aktifitas dalam ruangan) tapi juga outdoor activities (aktifitas luar ruangan) yang dikemas secara baik dan sistemik yang bermuara pada proses pembiasaan bersikap dan bertingkah laku yang baik dan positif berdasarkan nilainilai agama. Bentuknya tidak hanya sebatas praktek ibadah saja, tapi juga kegiatan-kegiatan inovatif lainnya yang di dalamnya berlangsung proses penanaman nilai-nilai akhlak mulia.

Peran guru PAI sebagai pembimbing harus dimaksimalkan. Lebih bagus lagi bila ditambah sebagai konselor yang melakukan tugas pendampingan terhadap peserta didik terutama mereka yang memiliki masalah baik dalam hal akademik maupun non akademik. Rata-rata peserta didik yang bermasalah di sekolah dan di luar sekolah berawal dari masalah rendahnya motivasi dan kurangnya perhatian dan kasih sayang dari keluarganya. Guru PAI harus tampil sebagai "juru selamat" mereka dalam membangkitkan kembali motivasi mereka dan percaya diri mereka. Interaksi dan komunikasi personal harus senantiasa dibangun tidak hanya di sekolah tapi juga di luar sekolah. Jikalau perlu home visit dilakukan sesekali untuk mencari tahu akar permasalahan peserta didik dalam rangka menemukan solusi yang tepat dalam mengatasinya atau memantau perkembangan mereka. Satu hal yang tak kalah pentingnya adalah setiap guru PAI harus selalu menyelipkan doa untuk kebaikan dan 
keberhasilan seluruh peserta didik mereka dalam munajat mereka kepada Tuhan. karena doa menurut keyakinan Islam bisa mengubah takdir.

Selanjutnya keteladanan harus menjadi perhatian serius setiap guru PAI. Guru PAI harus senantiasa berpegang teguh kepada kode etik profesional. Kode etik disini lebih dikhususkan lagi tekanannya pada perlunya memiliki akhlak yang mulia. Dengan akhlak yang demikian itu, maka seorang guru akan dijadikan panutan, contoh, dan teladan. Dengan cara demikian, ilmu yang diajarkan atau nasihat yang diberikannya kepada para peserta didik akan didengarkan dan dilaksanakannya dengan baik. tentang perlunya akhlak yang baik bagi seorang guru yang profesional ini sudah lama menjadi perhatian dan kajian para ulama Islam di zaman klasik. Ibn Muqaffa mengatakan bahwa guru yang baik adalah guru yang mau berusaha memulai dengan mendidik dirinya, memperbaiki tingkah lakunya, meluruskan pikirannya, dan menjaga kata-katanya terlebih dahulu sebelum menyampaikannya kepada orang lain. $^{23}$ sementara itu, Imam alGhazali menyatakan bahwa seorang guru yang menyampaikan ilmu pengetahuan harus berhati bersih, berbuat dan bersikap yang terpuji. ${ }^{24}$

${ }^{23}$ Ibn Muqaffa', al-Fiker al-Tarbawiy ind Ibn al-Muqaffa, sebagaimana dikutip Abuddin Nata, Manajemen Pendidikan, Mengatasi Kelemahan Pendidikan Islam di Indonesia, 158

${ }^{24}$ Imam al-Ghazali, Ibya Ulum al-Din, Jilid I, (Beirut: Dar al-Kutub, t.t.), 48-49

\section{KESIMPULAN}

Optimalisasi peran Guru PAI perlu dilakukan di tengah merosotnya sikap keimanan dan akhlak sebagian besar peserta didik dan lulusan pendidikan akhir-akhir ini. Optimalisasi peran guru PAI tersebut harus melibatkan berbagai unsur, yaitu pemerintah, lembaga pendidikan dan guru PAI itu sendiri. Pemerintah harus merumuskan dan menetapkan kebijakan khusus yang memberikan penguatan pembelajaran PAI di sekolah maupun di luar sekolah baik menyangkut perubahan kurikulum, fasilitas dan sumber belajar serta peningkatan kapasitas dan profesionalitas guru PAI. lembaga pendidikan sedapat mungkin menjadikan Pendidikan agama yang berorientasi pada peningkatan kualitas keimanan dan ketakwaan terhadap Tuhan YME sebagai core pengembangan pendidikan di sekolah melalui penciptaan kondisi sosiokultural sekolah yang dibangun atas nilai-nilai agama. Sedangkan guru PAI sendiri harus meningkatkan penguasaan bidang keilmuannya dan mengembangkan pendekatan pembelajaran PAI yang inovatif dan bertanggung jawab penuh. Meningkatkan perannya sebagai konselor yang melakukan tugas pendampingan terhadap peserta didik terutama mereka yang memiliki masalah baik dalam hal akademik maupun non akademik. Dan berpegang teguh pada kode etik guru profesional dalam kaitannya dengan akhlak mulia sehingga mereka menjadi teladan yang baik bagi para peserta didik mereka. 


\section{REFERENSI}

[1] Al-Ghazali, Imam, Ibya Ulum alDin, Jilid I, Beirut: Dar alKutub, tt.

[2] Daradjat, Zakiah, Metodik Khusus Pengajaran Agama Islam, Jakarta: Bumi Aksara, 2011.

[3] Djamarah, Syaiful Bahri, Guru dan Anak Didik dalam Interaksi Edukatif, Jakarta: Reneka Cipta, 2000.

[4] Langgulung, Hasan, Asas-Asas Pendidikan Islam, Jakarta: Pustaka Al-Husna Baru, 2003.

[5] Muhaimin, Nuansa Baru Pendidikan Islam, Mengurai Benang Kusut Dunia Pendidikan, Jakarta: RajaGrafindo Persada, 2006.

[6] Muhaimin, Rekonstruksi Pendidikan Islam, Jakarta: RajaGrafindo Persada, 2009.

[7] Nata, Abuddin, Manajemen Pendidikan, Mengatasi Kelemahan Pendidikan Islam di Indonesia, Jakarta: Kencana, 2010.

[8] Permendikbud Nomor 54 Tabun 2013 tentang Standar Kompetensi Lulusan

[9] Ramayulis, Ilmu Pendidikan Islam, Jakarta: Kalam Mulia, 2013.

[10] Sardiman AM, Interaksi dan Motivasi Belajar Mengajar, Jakarta:

Raja Grafindo persada, 2000.

[11] Suhertian, Piet, Profil Pendidik Profesional, Yogyakarta: Andi Offset, 1994.

[12] Tafsir, Ahmad, Filsafat Pendidikan Islam, Jakarta: Remaja Rosdakarya, 2006.
[13] Tafsir, Ahmad, Ilmu Pendidikan dalam Persfektif Islam, Bandung: Remaja Rosdakarya: 1994.

[14] Undang-undang Nomor 14 Tabun 2005 tentang Guru dan Dosen, Jakarta: Visimedia, 2008.

[15] Undang-Undang Sistem Pendidikan Nasional Nomor 2 Tabun 1989, Jakarta: Sinar Grafika, 1999.

[16] Uno, Hamzah B., Model Pembelajaran, Menciptakan Proses Belajar Mengajar yang Kreatif dan Efektif, Jakarta: Bumi Aksara, 2008.

[17] www.republika.co.id, Rabu, 12 November 2014

[18] www. riaupos.co.id, 17 Februari 2013

[19] www.kompasiana.com.

[20] www.netralnews.com, Rabu, 28 September 2016 